\title{
AN ASSESSMENT OF THE IMPLEMENTATION OF THE RE-ENTRY POLICY FOR GIRLS IN SWAZILAND: SCHOOL PRACTICES AND IMPLICATIONS FOR POLICY DEVELOPMENT
}

\author{
Qand'elihle G. S. N. Simelane, S'lungile Kindness Thwala, Thuli Mamba \\ University of Swaziland, Swaziland \\ E-mail: qandelihle@gmail.com, sskthwala@uniswa.sz
}

\begin{abstract}
Swaziland has no stand-alone re-entry policy. Practices vary from school to school, but generally a pregnant adolescent girl has to drop out of school although those who become pregnant may be allowed to return to write their exams at the same school or they may be advised to find another examination centre. The Swaziland Education and Training Sector Policy of 2011 (EDSEC) explicitly states that 'every child, irrespective of their life circumstances... has the right to be re-integrated into the same institution that the girl was previously attending.' The study documents school practices that appear to be informed by ignorance of the provisions of the EDSEC Policy of 2011 and historical developments in national policy; international conventions and declarations the country is signatory to, with missed opportunities. Schools are not coping with the evolving and expanding role in helping children develop. The study concludes that there is need for awareness raising as well as legislation which will compel schools not to expel such pupils but that they are given time to deliver their babies and be allowed to re-join the school. It is thought that institutionalising and publicising the EDSEC policy should lead to more and better reporting, more re-entry, and fewer abortions. There is necessity for awareness development among stakeholders, rigorous and vigorous campaigns and preparedness to tackle strong resistance which has been shown through the practices reported in this study to be hypocritical.
\end{abstract}

Key words: counselling, policy, practice, pregnancy, re-entry, Swaziland.

\section{Introduction}

The Ministries of education in some African countries have put in place a number of measures to ensure that, in accordance with their re-entry policies, adolenscents are admitted and retained in the educational system in line with national, regional, and international goals under various frameworks. These include, the Education for All Goals, the Millennium Development Goals (MDGs), and a number of international conventions. The right to education is one of the human rights entrenched in a number of international and regional human rights instruments. It is key because it gives way to the protection of other rights. Article 26 of the United Nations Universal Declaration of Human Rights states that education is a human right. The United Nations Convention on the Rights of the Child (CRC), Article 28, as well attests to this right. Furthermore, the United Nations Convention on the Elimination of Discrimination Against Women (CEDAW), the United Nations Platform for Action and the Beijing Declaration of 1995.

In domesticating the above international conventions and declarations to which Swaziland is a signatory, a number of policies and strategies have been embarked on. Notably one such strategy is the Re-entry Policy Statement in the 2011 Education and Training Sector Policy 
Qand'elihle G. S. N. SIMELANE, S'lungile KINDNESS THWALA, Thuli MAMBA. An Assessment of the Implementation of the Re-entry Policy for Girls in Swaziland: School Practices and Implications for Policy Development

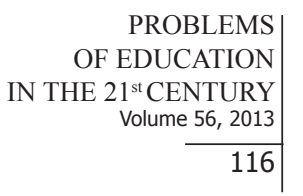

(viz: Burchinal, 1960; Bullock, Little \& Millham, 1994; Aikman and Unterhalter, 2005 and Chilisa, 2010; Omwancha, 2012). The Education and Training Sector Policy 2011, the section on Admission Criteria (Section 7.3), which is available on the web states that:

'Every child, irrespective of their life circumstances (teenage mothers, children in conflict with the law) has the right to be re-integrated into the same institution that the child was previously attending.'

The Education and Training Sector Policy (EDSEC) of 2011 has recently been launched. Stakeholder awareness is expected because the formulation of the EDSEC policy was widely consultative.

Education is of strategic importance to the Swaziland's economic growth acceleration, global competitiveness and its transformation into a knowledge and technology driven economy (Marope, 2010). The foundation of education in the country is a document on the philosophy, policies, and objectives of the Imbokodvo National Movement of 1969 (Imbokodvo National Movement Manifesto, 1969), which document has influenced developments in education and provided direction, emphasizing that "education is an inalienable right to every child and every citizen" in Swaziland.

The Education Statement of 1999 sought, amongst other things, provision of opportunities for all pupils of school going age and adults to develop themselves in order to improve the quality of their own lives and the standard of living of their own communities. Relevant to education, the National Gender policy, seeks to 'promote education as a basic human right ensuring that both female and male receive the same treatment and benefits at all levels; to make provisions for girls who fall pregnant to come back to school and continue with their studies after they have delivered.' The vision of the Ministry of Education and Training sets out the 'attainment of equality in educational opportunity for all pupils of school going age and adults, irrespective of their socio economic background, with the ultimate goal of enhancing their productive capacity, thus improving the quality of their lives' as a target.

\section{From Equality in Access to Education to Equity of Education Outcomes in Swaziland}

Traditionally, access to educational opportunities has been influenced by gender more than just the economic dynamics of the family. Boys have often been afforded the opportunity to access education ahead of their counterpart girls, which has led to the exclusion of many girls. Available recent information shows that boys fail, repeat and drop out of school in greater numbers than girls. According to recent reports, the flow of girls through the system is more efficient and smooth than boys'; thus, although boys outnumber girls, they are older, on average. It is evident that attitudes have changed, gender parity has been attained in overall access to education (Marope, 2010) and figures from the Educational Management of Information Systems (EMIS) in the Ministry of Education and Training indicate that the Swaziland education system now accommodates more girls than boys, especially at high school and tertiary education levels. There are generally more male than female students in the Swaziland education system. Hence, there are disparities still, not in equality but in equity, with males dominating the fields of mathematics and science, agriculture, commerce and postgraduate studies whereas humanities, education and health remain a predominantly feminine alternative (Marope, 2010).

\section{Student Drop Outs}

There are high repetition and dropout rates in the school system- both in primary (Fig. 1) and secondary (Fig. 2 and Fig. 3) school levels. In the document, Education for All Plan of Action, the GOS (2002) noted that there was evidence of high repetition rates throughout all grades. It takes approximately 13 years, on average, for a child to complete the 7 year primary 
school cycle. The repetition rates are highest in Form 2, of the secondary school years which is the adolescence stage. More students drop out due to lack of finances for school fees than

PROBLEMS

OF EDUCATION

IN THE $21^{\text {st }}$ CENTURY

Volume 56, 2013 pregnancy or any other cause. Whereas the number of students dropping out due to pregnancy increases as students reach adolescence (Figure 2 and Figure 3), the opposite is true with regards to numbers dropping out due to lack of funds. This speaks to the importance of providing funding for education and also indicates greater commitment by parents to the education of children as they approach adolescence stage.

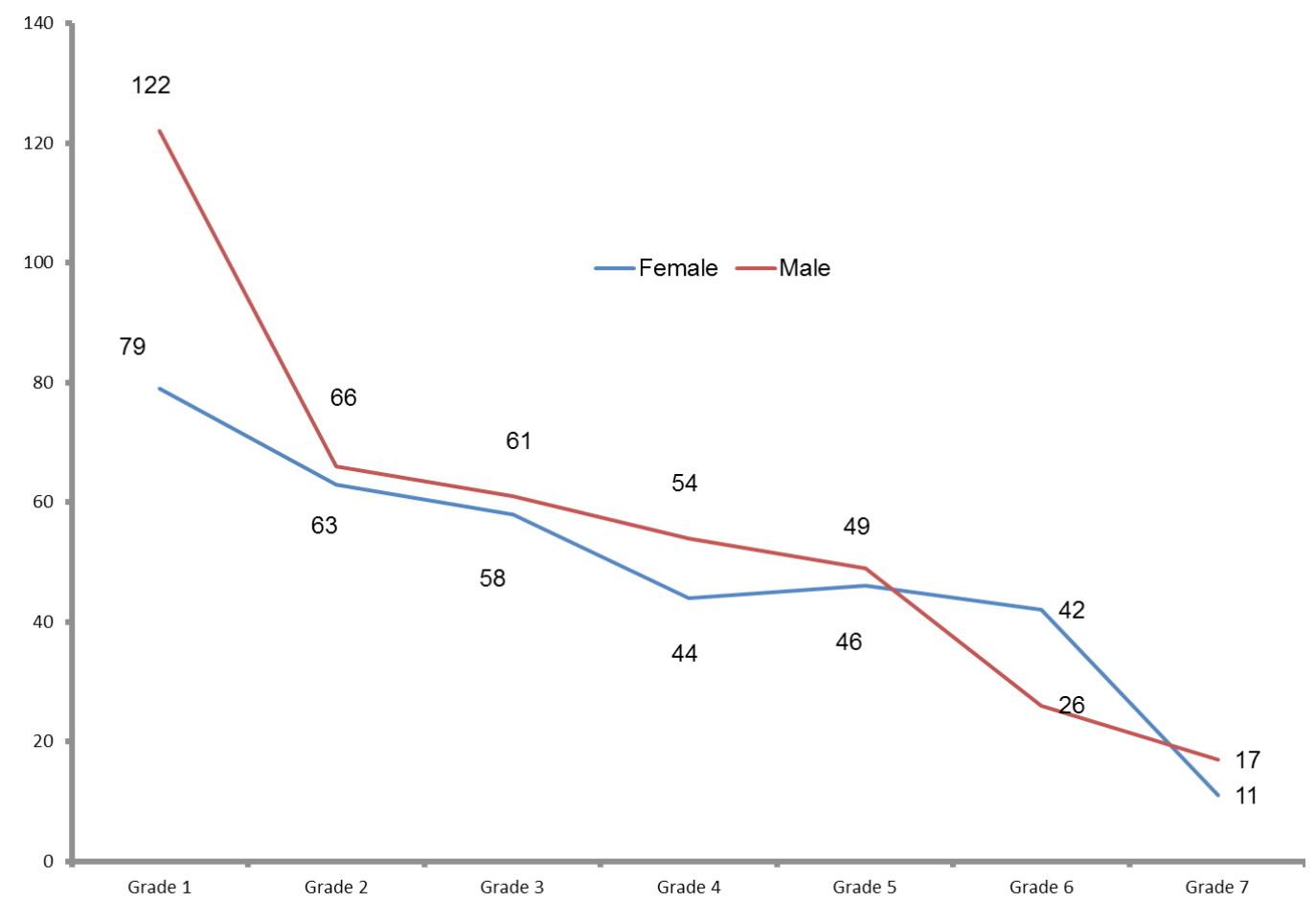

Figure 1: Trends in Primary School Students dropping out during 2010. Source: EMIS (2011).

Many girls, amongst those who have had access, drop out due to pregnancy while others would be withdrawn for arranged marriages and to care for their ailing parents and siblings. Mother pupils have often been excluded from the education system, in the absence of a formal arrangement for their return into the system.

\section{Methodology of the Study}

The study adopted a hermeneutic and interpretative stance which assumes that the researcher interprets and contextualises the data gathered. This perspective has epistemological roots in constructivism (Crotty, 2003) and relativist tradition (Robson, 2002). Interpretive hermeneutic approach was considered to be the most appropriate for this study research because of the growing conviction of the interactive and locally contingent nature of knowledge creation. From this perspective, instead of being a static, linear and cumulatively achieved reality discovered through the use of careful observation and logical deductions, knowledge construction is seen as circular, iterative and tentative. 
Qand'elihle G. S. N. SIMELANE, S'lungile KINDNESS THWALA, Thuli MAMBA. An Assessment of the Implementation of the Re-entry Policy for Girls in Swaziland: School Practices and Implications for Policy Development

OF EDUCATION

IN THE $21^{\text {st }}$ CENTURY

Volume 56,2013

\section{Demographic Characteristics of Participants}

Focus group discussions were held at two schools, as part of the data collection exercise and each group consisted of 4 female students and 8 males, respectively. Interviews were also conducted with Guidance and Counselling Teachers at these schools. One of the teachers was a male and the other a female. Two city schools Career Guidance and Counselling Teachers were also interviewed, both of whom were female. Administrators in the different schools were also contacted for student data as well as interviews. The study also benefitted from interviews with the Director at Pro-Learning High School, which is a private institution as well as Chairman at the schools where focus group discussions were held with the students.

\section{Data Collection Procedures}

The study covered 9 Manzini City High Schools; 7 selected schools JT High School to YZ High School in the transition between Manzini and Lubombo Districts as well 6 high schools in the Shielweni region, as part of the six -country study covering Malawi, Mozambique, Namibia, Swaziland, Zambia and Zimbabwe. The regional Consultant developed the instruments that were to be administered in all the six countries.

Qualitative semi-structured interviews and Focus Group Discussion were used in this study. The methods had four strands.

Strand 1: School (pupil, teachers and head teacher) perspective.

Strand 2: interviews with the FAWE National Coordinators and the programme officers; UNICEF; UNESCO; National Children Coordinating Unit (NCCU).

A triangulation of methods, integrating appropriate secondary and primary research methods was used. These included:

i. Desk review of relevant documents and materials related to the re-entry policy and policy formulation in general;

ii. Semi-structured interviews and focus group discussions with the FAWE chapters national coordinators, and the parent representatives, including the Ministry of Education officials at national level (headquarters);

iii. Site visits to selected schools in three districts purposively selected to represent the urban and rural schools.

Data on student drop outs, restarts and re-entry was collected from 4 cluster schools:

a. Manzini urban schools, from which drop outs due to pregnancy are expected to be high

b. Manzini-Siphofaneni Transect schools which may be expected to accept (as restarts or re-entry) girls and boys who drop out from urban schools.

c. Private schools, which may be expected to accept (as restarts or re-entry) girls and boys who drop out from public schools.

d. Shiselweni schools, a region where most people are poor in the country amidst the evidence of a link between poverty, higher child vulnerability rates, student pregnancy and dropout rates.

In each one of the schools, data were collected to establish the trends in student drop out, restart and re-entry over the past 5 years (2006-2011). Interview schedules were used in two selected schools, A and B. 


\section{Ethical Consideration}

Participation in the study was voluntary for all in the targeted population. In view of the ethical and legal consideration in conducting research, it was necessary to take into account the key requirements in the institutional review board (IRB) statements. Guidelines for conducting interviews with each of the respective groups were set out in the relevant interview schedules. This included explanations about the purpose of the study; assuring the participants that information they provided in the interviews would be treated with utmost confidentiality and was analysed along with other views from other schools in order to enable the Ministry improve on the processes of policy formulation and development.

\section{Results of Study}

The Education Management Information System (EMIS)

Information available from the Education Management Information Services indicates that in earlier grades, boys drop out of primary school in larger numbers, but the rate increases rapidly after Grade 3 amongst the girls, most of those who drop out in Grade 6 when the numbers of boys leaving the school system start to decline.

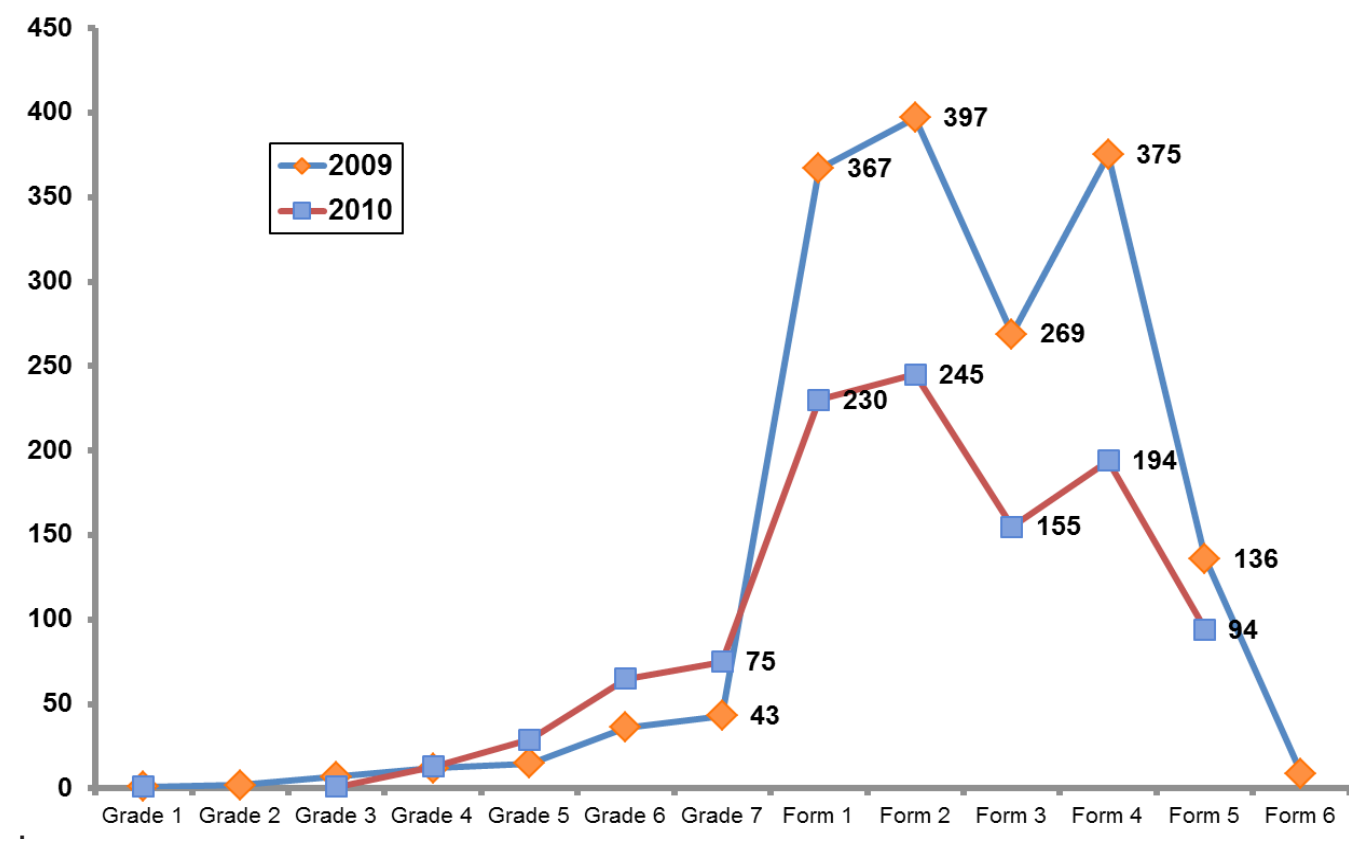

Figure 2: Trends in student drop outs amongst female students in Swaziland, 2009-2010.

The rapid increase in numbers amongst the girls dropping out of school after Grade 3 is shown to be due to high numbers of girls who become pregnant (Figure 2). The national school enrolment was 328, 081 pupils in the school system in 2010, and of these, a total of 7, 118 $(2.2 \%)$ dropped out. Most of those dropping out did so because they were either pregnant or due to failure to pay school fees. There were other reasons for dropping out, and these include absconding; death; disciplinary action; family reasons; sickness as well as transfers between schools. It is surprising that at primary school, the highest drop outs were in Grade 1 (Figure 1), in spite of the introduction of Free Primary Education in the same year (2010). 
PROBLEMS

OF EDUCATION

IN THE $21^{\text {st }}$ CENTURY

Volume 56, 2013

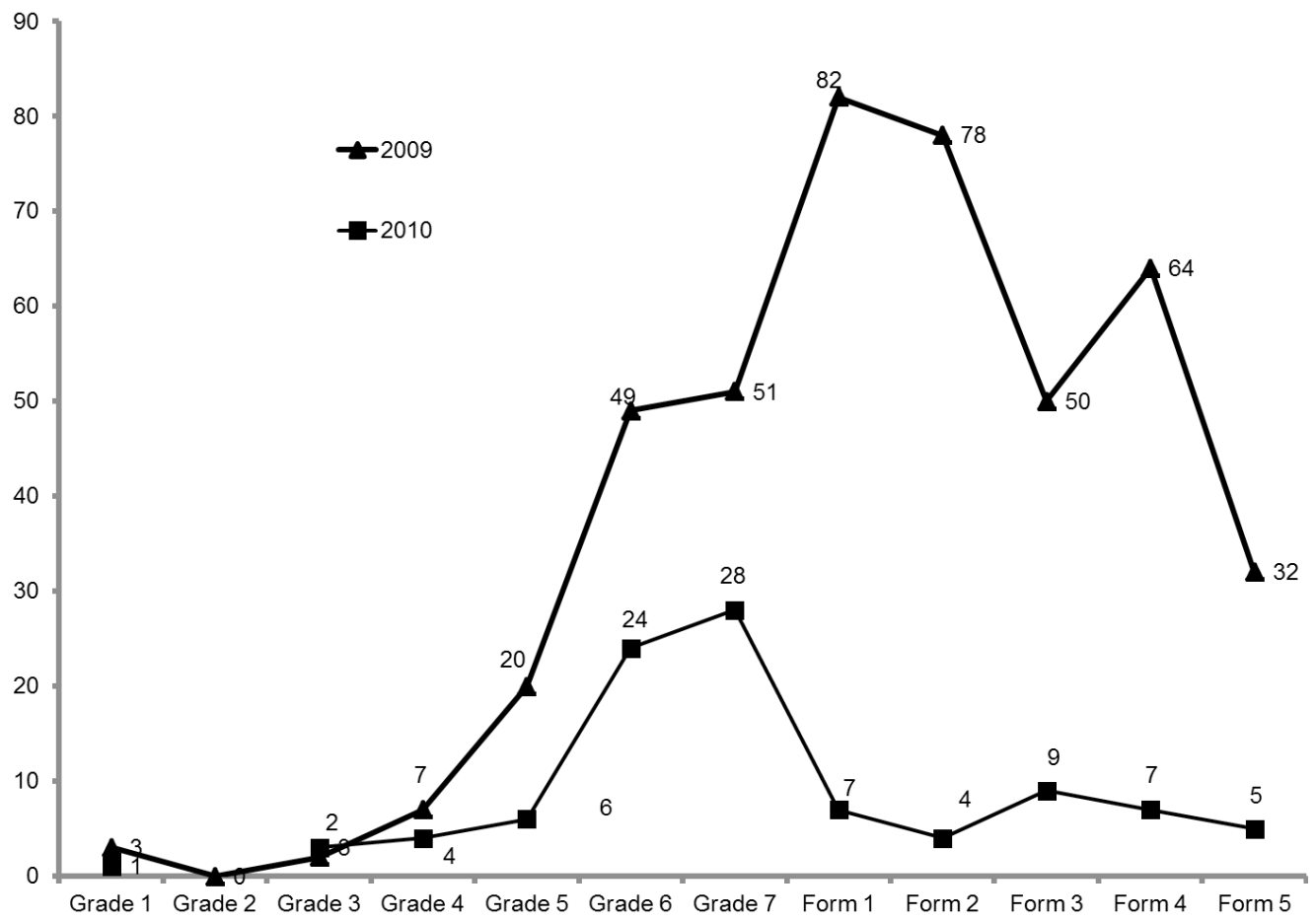

Figure 3: Trends in student drop outs amongst male students in Swaziland, 2009-2010

\section{School Visits}

Head teachers from the different schools were approached for information on the trends in student drop outs due to pregnancy and other causes covering the years 2006 to 2011 . There was a $40 \%$ response rate after 3 weeks of follow up calls and visits, with some schools making available data for only one year, 2011. Only one school reported re-entry students, and most head teachers could not account for even restarting students. Restarting students are those students re-joining the school system after being out of school for one year or more. In contrast, re-entry students are those adolescents re-joining the school system after being out of school due to pregnancy (see Lloyd \& Mensch, 2008; Hosie and Selman, 2002).

\section{Data Quality, Include Cases}

Discussions with the head teachers indicated that the statistics they provided for this study as well as official government records (Figure 1 to Figure 3) were full of inaccuracies. The head teachers conceded that some students disappear from their schools without formally reporting to them. Others who are pregnant may go through the academic year without being detected by the school. The head teachers cannot report with full confidence that the disappeared students were indeed pregnant, save for hearsay. Discussions with both teachers and students highlighted striking cases: Students who take their Junior Certificate (Form 3 or Grade 10) exams with a pregnancy and they miss the attention of the school. They give birth at the end of the year, after their examinations, and return the following year for the last two years of their education. Form 5 students who become pregnant often do write their examinations carrying a pregnancy. . Some schools produce Christmas babies. This does occur in both public and private schools. 
One head teacher cited a case where the student's mother came to report their daugh-

PROBLEMS

OF EDUCATION

IN THE $21^{\text {st }}$ CENTURY

Volume 56, 2013 ter's pregnancy (after being given a hint by another parent who has a child enrolled in their daughter's school), seeking direction from the school. The parent returned within a week and reported the birth of a child. 'The pupil had carried the pregnancy to full term, in the full school uniform and without being detected by school authorities!'... The resolution was to 'let the girl take care of the new born baby and return to school as soon as possible. After all, the school had not been able to see it all.'

There are a number of similar cases within the Swaziland school systems, and their occurrences vary from year to year and from school to school.

\section{The Health Management Information System (HMIS)}

In view of the limitations to the information provided by schools and in the official Ministry of Education and Training reports, data on adolescents' antenatal attendance and institutional deliveries was sought from the Health Management Information System of the Ministry of Health. The idea was to develop a better picture on numbers of school going age mothers in the country. In this case, the age group 14-19 years was of interest. It is especially important to note that fewer girls are over aged in the Swaziland Education System as highlighted earlier in this report. At junior secondary level, there are more appropriately aged boys than girls $(\mathrm{GER}=0.92, \mathrm{NER}=1.36)$, and this is also true of senior secondary level $(\mathrm{GER}=0.95$, $\mathrm{NER}=1.12$ ). Therefore this data is very appropriate to make inferences about high school and their child bearing. Although some of these teenage mothers may be out of school, school attendance ratios are generally high in this age group.

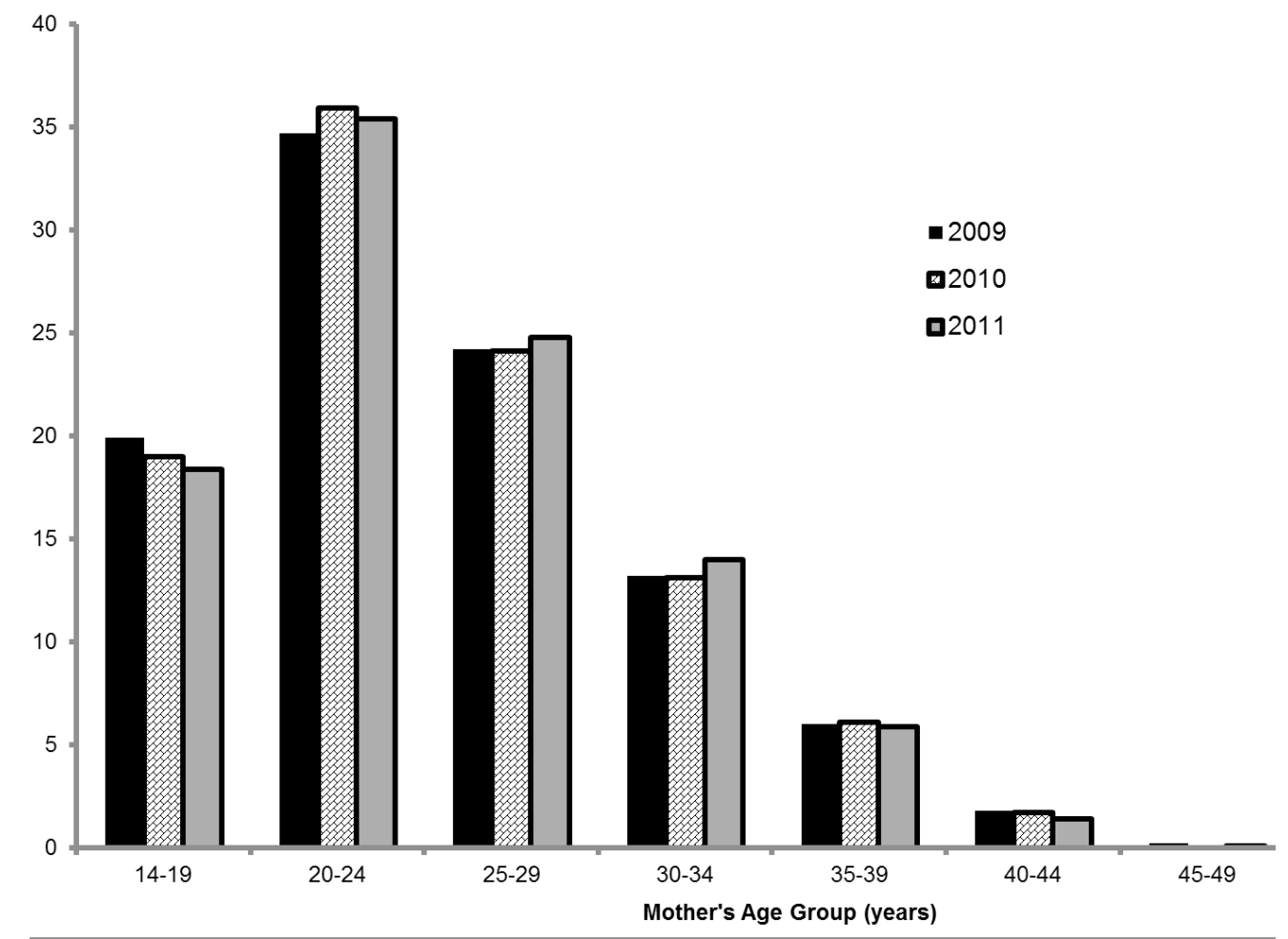

Figure 4: Inpatient Deliveries by Age Group 2009 - 2011. Source: HMIS (2012). 
Qand'elihle G. S. N. SIMELANE, S'lungile KINDNESS THWALA, Thuli MAMBA. An Assessment of the Implementation of the Re-entry Policy for Girls in Swaziland: School Practices and Implications for Policy Development

EMS

OF EDUCATION

IN THE $21^{\text {st }}$ CENTURY

Volume 56, 2013

Information on institutional deliveries, which also reflects the age of the mother, was obtained and is presented in Figure 4 and Table 3 indicating that teenage mothers account for 1 in $5(18-20 \%)$ of mothers in institutional deliveries (Figure 4; and amongst these teenage mothers, 2 in 3 of them (over 66\%) is within the age 18-19 years (Table 3 ). This implies that most of the girls become pregnant during their last year of school (aged 18 years) and if not, they become parents during the first year after completing school (aged $<20$ years).

Information presented in Table 3 and Figure 4 when compared with data in Fig. 2 contrasts starkly with the pregnancy dropouts totalling between 1100 and 1670 over the years 2010 and 2009. In comparison, there were between 3870 and 3864 institutional deliveries of women of the same school going age group, over these respective years (Table 3 and Figure 4). Although school drop outs include Grades 3 to Form 6, pregnancy drop outs equate to less than a third of the number of deliveries. There may however, be girls who were out of school already amongst the 14-19 year old mothers, but in the same age group may not deliver in formal institutions.

Table 3. Swaziland Inpatient Deliveries among Teenagers (2009 - 2011).

\begin{tabular}{lllllllll}
\hline \multirow{2}{*}{ Age Group } & $\mathbf{2 0 0 9}$ & \multicolumn{2}{c}{$\mathbf{2 0 1 0}$} & $\mathbf{2 0 1 1}$ & \multicolumn{3}{c}{ Total } \\
\cline { 2 - 9 } & $\mathbf{n}$ & $\mathbf{n}$ & $\mathbf{n}$ & $\mathbf{6}$ & $\mathbf{n}$ & $\%$ & $\mathbf{n}$ & $\%$ \\
\hline 14-15yrs & 143 & 3.7 & 123 & 3.2 & 114 & 3.1 & 380 & 3.3 \\
\hline 16-17yrs & 1162 & 30.1 & 1176 & 30.4 & 1098 & 29.7 & 3436 & 30.1 \\
\hline 18-19yrs & 2559 & 66.2 & 2571 & 66.4 & 2482 & 67.2 & 7612 & 66.6 \\
\hline Total & 3864 & 100.0 & 3870 & 100.0 & 3694 & 100.0 & 11428 & 100.0 \\
\hline Source: & HMIS (2012) & & & & & &
\end{tabular}

One discussant teacher explained the trend amongst the 18-19 year olds by observing that:

"Some of the girls finish school with their virginity intact; and promise to go 'all out with school to complete'. They exclaim, 'ngaphose ngafa kubaliselwa ngesikolwa....' which translates to 'so much persistent talk about having to finish school...'). And now I can have as much sex. And they become pregnant."

Other studies in South Africa have recorded this as the age when most girls lose their virginity, especially during their first year at university (Mulwo and Tomaselli, 2009).

\section{Policy Implementation}

The policy document has recently been launched and it is available on the Swaziland Government website. Girls are readmitted into schools other than the ones in which they were originally enrolled, but monitoring their performance is not easy because of poor record keeping and a lack of 'tagging'. There are therefore no statistics regarding their performance and completion rates. School administrators and teachers were skeptical about tagging the student mothers suggesting that it may constitute stigmatisation (see Bullock, Little \& Millham, 1994). Orphans and vulnerable children (OVCs) have been tagged- in the media, displayed with their images- with relatively positive benefits for the children. 


\section{School Practices}

Schools were found to occur within a spectrum of exclusionist to re-entry school, depending on their practices and attitudes towards pregnant girls. These extremities were encountered amongst the Manzini City Schools:

\section{a. Exclusionist}

In exclusionist schools, the fate of the pregnant girl depends on the teacher involved, and one teacher may report directly to the head. The teacher may approach the student; advise her to keep away from open areas or the line of sight of some teachers. She/ he would ask how old the pregnancy is so they can give 'appropriate' advice. If she (the student) is likely to give birth in December, advise them to stay on and finish the year. If however, the story reaches the head teacher, s/he tells the student to leave school, never to come back because of pregnancy.

\section{b. Re-entry School}

In one re-entry school, most pregnant students disappear without questioning and only about $10 \%$ appear for counselling. The head teacher never sends a pregnant student home. Some deliver the baby (or abort) and return to the school after a week or two. Whether the child is delivered or aborted, teachers are afraid to confront the student, even though they suspect. Therefore, dropping out due to a pregnancy is 'voluntary'.

c. Why exclude

Submissions from focus group discussions held with students and teachers as well as parent representatives indicated that, much against the EDSEC Policy of 2011 and the wishes expressed in the National Policy Framework of 1999, pregnant students are often 'advised' to drop out of school once they are 'known' to be pregnant. The term 'advised' is used in this context because school authorities argue that it is in the interest of both the pregnant student and their colleagues to keep the pregnant student out of school.

With regards to the pregnant student, issues of stigma are cited, together with arguments that she may not be a good example to the rest of the students with their pregnancy. A member (Chairman) of a City School PTA observed that keeping a pregnant student in the school system may:

'set a bad precedence, function against the teachings of the school guidance and counselling services as well as Christian teachings upon which many schools are founded... and it would be against government initiatives.'

Schools DO keep pregnant students, to the completion of the pregnancy term and also enrol student mothers or re-entry students. Government policy on re-entry is non-existent to the many that are unaware of its existence; its representation depends on interpretations of the 1999 Policy Framework and the inclination of the school official. Practice is influenced by the words and pronunciations of different officials such that they may only prevail over the duration of the tenure of their office:

Head teacher in the east:

'A pregnant student has to move and seek a place to enrol in a different REGION/ DISTRICT once the baby is born...'

Student in the Manzini City:

'...yes! Recently the head teacher said the new policy dictates that if the boy who is responsible for the pregnancy is at the same school, he will have to go home together with the soon-to-be mother of his baby.' 
Qand'elihle G. S. N. SIMELANE, S'lungile KINDNESS THWALA, Thuli MAMBA. An Assessment of the Implementation of the Re-entry Policy for Girls in Swaziland: School Practices and Implications for Policy Development

PROBLEMS

OF EDUCATION

IN THE $21^{\text {st }}$ CENTURY

Volume 56, 2013

124

Students show empathy and sympathy with their pregnant colleagues, and help them avoid getting noticed by the school administration, hence avoid expulsion. Experience in the field also shows that students collaborate with their teachers to conceal a pregnancy from other teachers (who may report to the administration) and to the school administration itself. The students, in these cases, would be well aware of the pregnancy and do not stigmatise the pregnant colleague.

Before the Ministry of Education and Training intervened, some schools, through their PTAs, had adopted the practice of testing female students for pregnancy at the beginning of the year. Teachers report that some of the tests would turn out positive, but scans would show no foetus which would point to a terminated pregnancy. Guidance Counsellors also account for students who show signs of pregnancy for weeks, but such signs would disappear over time. These abortions, the Guidance Counsellors concede, may account for the low dropout rates in the city schools:

'Abortion is common. One girl committed an abortion in the school hostel toilet, but the foetus died on the way to hospital. Abortion facilities are readily available. Consider reports of foetuses found around Mbikwakhe, many of them were from students. A woman at Bhunya Market used a knitting needle to help girls abort...Marie Stoppes in South Africa is a short drive away from Swaziland!' (Guidance and Counselling Teacher from 'Exclusionist School').

There could even be greater awareness about pregnancy prevention:

'There are now fewer pregnancies; fewer students are suspected of having committed an abortion...prevention must be working. It is the junior classes of novices where you have pregnancies, and there are fewer in the senior classes...' (Guidance and Counselling Teacher from 'Re-Entry School')

'Pregnancy rates down, open talk about contraception and services are easier to obtain from FLAS. FLAS gives services without question.' (Guidance and Counselling Teacher from 'Exclusionist School')

\section{Who Makes the Girls Pregnant?}

Lax parenting and a celebrity-driven culture of instant gratification is forcing schools to act as "surrogate parents" for many pupils. A culture which is sometimes self-obsessed and puts such emphasis on celebrity and self-gratification doesn't ... foster in our young people the essential virtues of effort and diligence which are so fundamental to our success at schools.

In spite of the reports of abuse (see Ruto, 2009), FGDs with the students portrayed girls as lovers of 'colour' and 'good' things. They run for bus conductors; soccer stars, in and out of school; dancing males; rappers/ artists; athletic boys and man; wealthy, older men. Peer pressure and attempts to please these boyfriends may then lead to sex that yields a pregnancy. The students noted, during the FDGs, that vulnerability may expose the girls, but many that become pregnant are not vulnerable. They however observed that, without a good understanding of the life situation of the girl child, it is not easy to dismiss any association of a pregnancy with vulnerability.

Hence there is a call for schools to combat a growing emphasis on instant gratification. TV shows convince children that it was possible to immediately succeed without doing any work. Youngsters are too often exposed to double standards - where bad behaviour and violence are publicly condemned but endlessly available as entertainment.

\section{Conclusions}

There is need to put in place a number of measures to ensure that girls and boys are admitted and retained in the education system in line with national, regional, and international goals under various frameworks. 


\section{Life Skills and Orientation}

During focus group discussions with students, they indicated that they had no regular sessions with their Career Guidance and Counselling teachers. The teachers themselves reported their frustrations with the amount of work associated with the responsibility, all of which is added to their regular teaching duties. The students obtain information on life skills and orientation as well as sex education from friends, pamphlets from FLAS and similar organisations as well as the media. Considering how important this aspect of child development is in the development of the child, and how casual it is treated, the inference could be that it would still be possible to teach them Mathematics and Science in the same way and expect them to make it in the examination (of life in this instance).

The EDSEC Policy of 2011 is explicitly clear that 'every child, irrespective of their life circumstances has the right to be re-integrated into the same institution that the child was previously attending.' This needs to be brought to the attention of all stakeholders, including students, teachers, school administrators and parents so that each is aware of their rights and obligations.

In Swaziland schools, students attend classes with pregnant colleagues who carry their pregnancies to the end of the term without the school administrators finding out. Students attend classes with colleagues who are parents and do not stigmatise them. With better counselling services, which are generally lacking in schools at the moment, Swazi schools may better help develop student mothers to complete schools and further their accommodation with less stigma than they currently experience. The empathy and sympathy amongst the students are often underestimated- and so is their level of maturity which enables them to live with colleagues who have terminated pregnancy.

\section{Professionalism in Education Management}

There was a feeling amongst discussant teachers and parent representatives that decisions related to education should be the work of education professionals. The teachers find themselves functioning as implementers of policy decisions regarding which they never get consulted. The lack of proper, effective and active participation is probably reflected in the lack of awareness even amongst school head teachers on whom practice depends at the moment.

\section{Recommendations}

Institutionalising and publicising the recently launched EDSEC policy should lead to more and better reporting, more re-entry, fewer abortions, especially backstreet abortions. There is therefore need for awareness development among stakeholders, rigorous and vigorous campaigns and preparedness to tackle strong resistance shown through the practices reported in this study to hypocritical. For instance, one deputy head teacher in a city school insisted that they:

"I want it recorded that the Deputy Head of School X said, we don't want our schools to be turned into what we see in South Africa where girls bring pregnancies to school...tell this to your colleagues."

She had admitted though that she had a student mother whom she sneaked into the school this year, 2012. She insisted there had been no girls dropping out from their school (2006-2011), due to pregnancy or other reasons for dropping out, against accounts from teachers and students that pregnant students write their exam in the 'dining hall' not the school hall where the rest sit; the school had recently been in the media for expelling students who had skipped from the hostel, yet she asserted that as a Mission school, they help advise and not expel students. 
Qand'elihle G. S. N. SIMELANE, S'lungile KINDNESS THWALA, Thuli MAMBA. An Assessment of the Implementation of the Re-entry Policy for Girls in Swaziland: School Practices and Implications for Policy Development

\section{PROBLEMS \\ OF EDUCATION \\ IN THE $21^{\text {st }}$ CENTURY \\ Volume 56, 2013 \\ 126 References}

Burchinal, L. G. (1960). School Policies and School Age Marriages. The Family Life Coordinator, 8 (3), 43-48

Bullock, R., Little, M., \& Millham, S. (1994). Children's Return from State Care to School, 20 (3), 307-316. Retrieved 05/11/2013 from http://www.tandfonline.com/doi/ pdf/10.1080/0305498940200304.

Chilisa, B. (2010). National Policies on Pregnancy in Education Systems in Sub-Saharan Africa: The case of Botswana. Retrieved 03/11/2012 from http://www.tandfonline.com/doi/ pdf $/ 10.1080 / 09540250120098852$.

Dube, M. M. A. (2010). Capacity Building on Open and Distance Learning Project: Four Sector Study (Swaziland). Study Commissioned by the Southern African Development Community (SADC)

Elimu, Y.C. (2005). The challenge of educating girls in Kenya. In: Aikman, S., Unterhalter, E. Eds. (2005). Beyond Access: Transforming Policy and Practice for Gender Equality in Education. Oxfam GB

Government of Swaziland (2010). Kingdom of Swaziland. Towards a Strategic Plan for the Education Sector: World Bank.

Hosie, A., \& Selman, P. (2002). Teenage Pregnancy in Young Women of School Age: an exploration of disengagement from the education system. Paper presented at the Young Parents in Ireland Conference Dublin. Retrieved 01/11/2013 from http://www.alisonhosie.co.uk/pdf/TPU_ and_edu/Pregnancy_and_motherhood_in_young_women_of_school-age.pdf.

Imbokodvo National Movement (1969). The Philosophy, Policies and Objectives of the Imbokodvo National Movement. Mbbane: Swaziland Government

Lloyd, C. B., \& Mensch. B. S. (2008). Marriage and childbirth as factors in dropping out from school: An analysis of DHS data from sub-Saharan Africa, 62 (1), 3-20. Retrieved 12/10/2013 from http://www.tandfonline.com/doi/pdf/10.1080/00324720701810840. Date Accessed: October 12, 2013

Marope, M. (2010). The Education System in Swaziland: Training and Skills Development for Shared Growth and Competitiveness. Washington: The International Bank for Reconstruction and Development of the World Bank

Ministry of Economic Planning and Development (2007). The Poverty Reduction Strategy and Action Plan. Retrieved12/01/2012 from http://planipolis.iiep.unesco.org/upload/Swaziland/Swaziland_draft_PRSP_2005.pdf.

Mulwo, A., \& Tomaselli, K. G. (2009). Sex, morality and AIDS: The perils of moralistic discourses in HIV prevention campaigns among university students. Communicatio: South African Journal for Communication Theory \& Research, 35 (2), 295-314. doi:10.1080/02500160903250705.

Omwancha, K. M. (2012). The implementation of an educational re-entry policy for girls after teenage pregnancy: A case study of public secondary schools in the Kuria District, Kenya. A thesis submitted to the Victoria University of Wellington in fulfilment of the requirement for the degree of Doctor of Philosophy in Education: Victoria University of Wellington. Retrieved 08/09/2013 from http://researcharchive.vuw.ac.nz/bitstream/handle/10063/2382/thesis. pdf? sequence $=1$

Ruto, S. J. (2009). Sexual abuse of school age children: Evidence from Kenya. Journal of International Cooperation in Education, 12 (1), 177-192.

Swaziland Government (2010). Free primary education. Ministry of Education and Training, Mbabane, Swaziland.

Swaziland Government (1999). National Policy Statement on Education. Mbabane: Swaziland Governemnt.

Swaziland Government (1999). National Development Strategy (NDS).Vision 2022: Key macro and sectoral strategies. Mbabane: Swaziland Government.

Swaziland Government (2009). National development plan 2009/10-2011/12. Economic Planning Office, Ministry of Economic Planning and Development. Mbabane: Swaziland Government. 
Qand'elihle G. S. N. SIMELANE, S'lungile KINDNESS THWALA, Thuli MAMBA. An Assessment of the Implementation of the Re-entry Policy for Girls in Swaziland: School Practices and Implications for Policy Development

PROBLEMS

OF EDUCATION

IN THE $21^{\text {st }}$ CENTURY

Volume 56, 2013

Advised by Miroslaw Kowalski, University of Zielona Gora, Poland

127

Received: November 08, 2013

Accepted: November 21, 2013

Qand'elihle G. S. N. Simelane Research Consultant, P.O. Box 5875, Manzini, Swaziland.

Mobile: + 26876043002 .

E-mail: qandelihle@gmail.com

S'lungile Kindness Thwala

Lecturer in the Department of Educational Foundations and Management, University of Swaziland, P/B no.4, Kwaluseni, Swaziland.

E-mail: sskthwala@uniswa.sz

Thuli Mamba

Students Counsellor, University of Swaziland, Luyengo Campus, P.O. Luyengo, M205, Swaziland.

E-mail:tmamba@uniswa.sz 